A Petz Aladár Megyei Oktató Kórház, Orthopaediai Osztály és a Balesetsebészeti és Kézsebészeti Osztály² közleménye

\title{
Fiatal felnőttkori, töréssel és nagy dislocatióval szövődött elülső-radialis könyökficam ellátása, eredménye
}

\author{
DR. NYÓGÉR ZOLTÁN ${ }^{1,2}$, DR. GUNTHER TIBOR ${ }^{1,2}$, DR. BALOGH PÉTER²
}

Érkezett: 2020. április 2.

DOI: 10.21755/MTO.2020.063.0104.005

\section{ÖSSZEFOGLALÁS}

A szerzők egy töréssel szövődött elülső-radialis könyökficam esetét mutatják be, a sérülés mútéti ellátásától kezdve a posztoperatív rögzítésen keresztül, egészen a rehabilitációig. A mútéti ellátásnál külön felhívva a figyelmet a repositiós akadály lehetőségére, illetve a szalagrendszer sérülésének megfelelő felmérésére, valamint annak stabilizálására. A posztoperatív kezelésnél a szerzők hangsúlyozzák a korai rehabilitáció megkezdésének fontosságát.

\section{Kulcsszavak: Ficam; Könyöksérülés; Töréskezelés; Szalagsérülés; Rehabilitáció;}

Z. Nyoger, T. Gunther, P. Balogh: Treatment and result of juvenile anterior elbow dislocation with fracture

The authors report a case of anterior-radial elbow dislocation with fracture, ranging from surgical treatment of the injury to postoperative fixation to rehabilitation. In surgical care, special attention should be given to the possibility of reduction obstruction and the proper assessment of the ligament injuries and stabilization of them. In postoperative care, the authors emphasize the importance of starting early rehabilitation.

Keywords: $\quad$ Adolescent; Elbow joint - Injuries; Fractures, bone - Complications; Joint dislocations - Complication/Rehabilitation/Surgery;

Ligaments - Injuries; 


\section{BEVEZETÉS}

A könyöktáji ficamok döntő többsége dorsalis irányú ficam, ventralis irányú ficam csak az esetek nagyon kis százalékában fordul elő $(5,11,12)$. A sérülés a könyökízület hajlított helyzete mellett alakul ki, amikor a könyökcsúcsot hátsó irányból a sérülés pillanatában erőbehatás éri (6). A ventralis irányú ficam kihívást jelent a sebész számára. Részben a sérülés lokalizációjából adódó esetleges idegsérülés, másrészt, ami sürgősségi szempontból még fontosabb, a lehetséges érsérülések és következményes keringési zavarok fellépése miatt $(5,13)$. Késői szövődményként pedig számolni kell a mozgástartományban kialakult elmaradásokkal, fokozott hegesedéssel (14), krónikus instabilitással (3), periarticularis ossificatióval $(3,5)$, amelyek sok esetben csak hosszas gyógytorna, néhány esetben pedig csak sebészi felszabadítás révén javíthatók. A könyökízületben kialakult incongruentia és mozgáselmaradás korai arthrosishoz vezethet (2).

\section{ESETISMERTETÉS}

$\mathrm{Az}$ esetismertetésben egy 18 éves fiatal férfi sérülését mutatjuk be, aki judo versenyen szenvedett súlyos, jobb oldali (domináns oldal) könyöktáji sérülést (1. ábra). A versenyről mentő szállította a Sürgősségi Betegellátó Osztály Traumatológiai Egységére, sérült végtagját karfelkötőben rögzítették. Az elkészített röntgenfelvételeken medialis epicondylus töréssel és lateralis condylus abruptiós töréssel szövődött elülső könyökficamot észleltünk.

A fizikális vizsgálat során gyenge pulzust detektáltunk, illetve a nervus ulnaris beidegzésének megfelelően zsibbadásos panaszokat jelzett a sérült. Az ambulancián aneszteziológus által vezetett maszkos narkózisban próbáltuk reponálni a törést, amely sikertelen volt (2. ábra). Így akut mútét elvégzése vált szükségessé.

Tekintettel a sérült által jelzett nervus ulnaris beidegzésének megfelelő zsibbadásra medialis oldali behatolással kezdtük a mútétet. A medialis epicondylus feltárását követően felkerestük a nervus ulnarist, amelyet szintén kipreparáltunk. A nervus ulnaris is ventralis irányba mozdult el a medialis epicondylussal együtt (3. ábra). Folytonossága megtartott maradt, makroszkópos sérülést az idegen nem találtunk (4. ábra). Feltehetően a medialis oldalon a törési rés területére ékelődött lágyrész interpositum miatt nem volt lehetséges a fedett repozíció elvégzése. Miután a medialis oldalon a törési rést megtisztítottuk és az interpositumot megszüntettük a ficam repositiója már lehetségessé vált. Ezt követően az epicondylus anatómiai repositiója is kivitelezhető volt, amely után a nervus ulnaris is helyére került. A medialis törtdarabot 2 darab KFI 3,5 mm-es végén menetes spongiosa csavarral rögzítettük, ügyelve arra, hogy a csavarok vége ne érjen bele a fossa olecrani területébe, egy lehetséges mechanikai extenziós elmaradást okozva (4. ábra). A csavaros rögzítést követően a nervus ulnaris helyzete a könyök átmozgatása során stabil volt, luxatiós, subluxatiós tendenciát nem észleltünk. A medialis collateralis szalagrendszer intakt volt, így valgus irányú intraoperatív tesztre felnyílás nem jelentkezett.

A lateralis oldalon a szalagrendszer abruptiós mechanizmussal sérült, ennek következtében varus irányú stresszre egyértelmű, jelentős mértékű felnyílást észleltünk, illetve Pivot-Shift tesztre posterolateralis instabilitás jelentkezett. Emiatt a lateralis oldal stabilizálása mellett döntöttünk. Lateralis feltárás után az egész lateralis szalagrendszer epicondylusról való leszakadását találtuk, kisméretű abruptiós csontsérülés mellett (5. ábra). Az ízületet a radialis collateralis szalag $(R C L)$ és lateralis ulnaris collateralis szalag (LUCL) közötti térben megnyitottuk.

Tekintettel a kisméretű abruptiós csontdarabokra csavaros rögzítés nem volt lehetséges. Horgonyos rögzítés mellett döntöttünk, amely során ORFI II-es horgonyokat alkalmaztunk. A horgonyokat egyenként két pár 0-ás Vicryl fonallal töltöttük (6. ábra). A horgonyokat a radialis epicondylus területére ültettük be az $R C L$ és $L U C L$ eredési területének megfelelően. Ezt követően az RCL-t és a LUCL-t horizontális matracöltésekkel az eredési területére rögzítettük (7. ábra).

Miután a medialis és a lateralis oldali rögzítés is megtörtént, ellenőriztük a stabilitást, varus és valgus, valamint Pivot-Shift tesztre felnyílás, instabilitás egyik oldalon sem volt észlelhető. A stabilitási próbák után ellenőriztük a könyökízület mozgástartományát, mind a flexiós-extenziós, mind a pronatiós-supinatiós 
mozgások teljesek voltak. A könyök mozgatása során még egyszer külön figyelmet fordítottunk a nervus ulnaris vizsgálatára. Sem subluxatiós, sem luxatiós tendenciát nem észleltünk. A sebeket drain felett zártuk, majd magas dorsalis gipszsínt helyeztünk fel (8. ábra).

A posztoperatív kezelés során 3 hétig alkalmaztunk magas dorsalis gipszsín rögzítést, de minden nap több alkalommal engedélyeztük a gipszsín eltávolítását, amelyet követően kezdetben gyógytornász segítségével, emissziót követően pedig önállóan végezte a beteg a gyógytorna feladatokat. $A 3$. hét végére a gipsz teljes elhagyásakor 15 fokos flexiós és 20 fokos extenziós elmaradást, valamint pronatióban és supinatióban 30-30 fokos elmaradást észleltünk. A további intenzív gyógytorna hatására a 10 hetes kontrollon már csak 10 fokos extenziós elmaradás maradt, a többi mozgástartomány az ellenoldalival azonossá vált. A 15 hetes kontroll során már extenziós elmaradást sem észleltünk, a szalagrendszer teljesen stabil volt, felnyílás nem volt sem a medialis sem a lateralis oldalon (9. ábra). A sérüléstől számított 1 év után Mayo Elbow Performance Score és Oxford Elbow Score segítségével objektivizáltuk a könyökízület funkcióját, mindkét scoron kitűnő eredmény született. A fiatalember visszatért a judohoz, ugyanolyan versenyzői szintre, amelyet a sérülés előtt végzett.

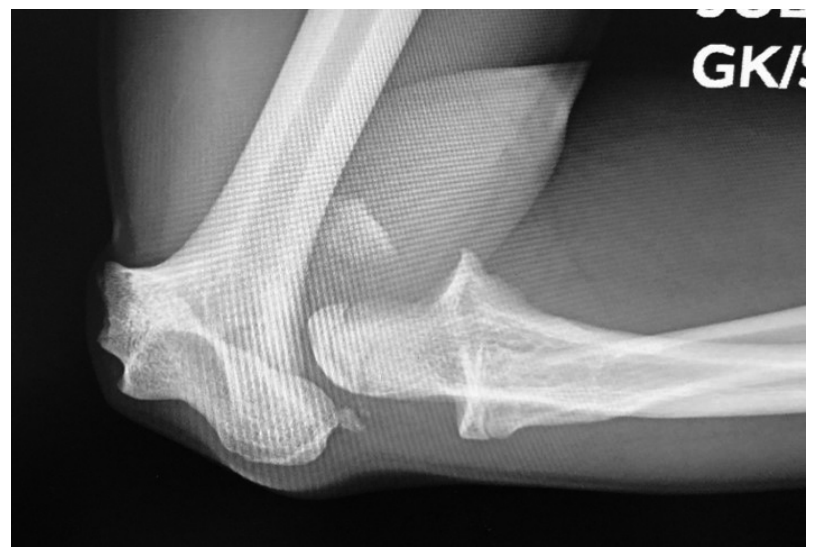

1. ábra

Töréssel szövődött elülső könyökficam röntgenképe

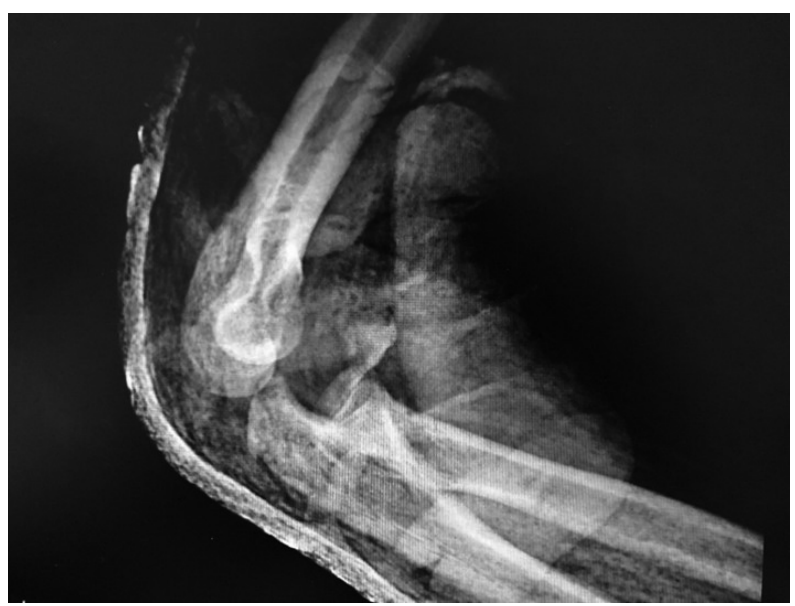

2. ábra

Narkózisban történt repozíciós kísérlet utáni állapot 


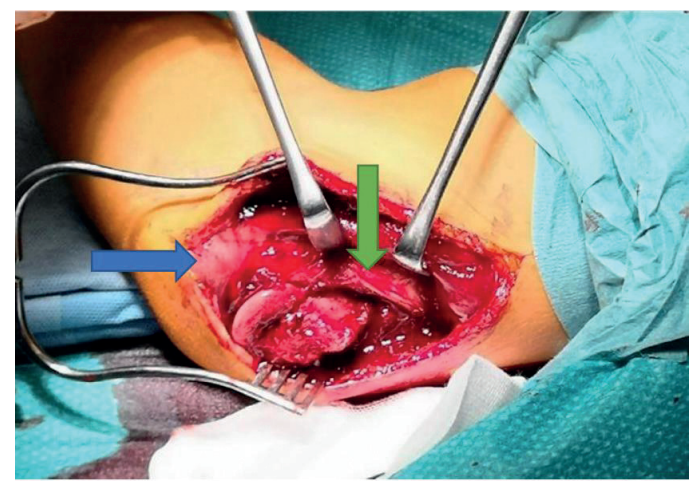

3. ábra

Medialis feltárás utáni állapot, a zöld nyíl a nervus ulnarisra mutat, amely ventralis irányba dislocalódott, a kék nyil a dislocalódott medialis epicondylust jelzi

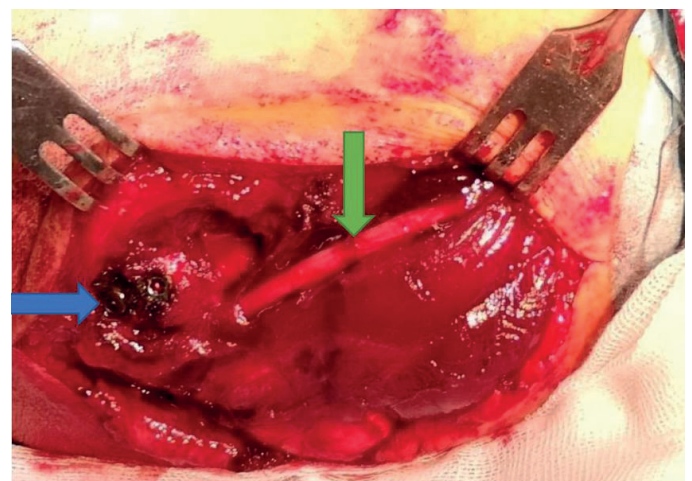

4. ábra

Reponált és KFI csavarokkal rögzített medialis epicondylus (kék nyíl), a nervus ulnaris proximalis szakasza kipreparálva (zöld nyíl)
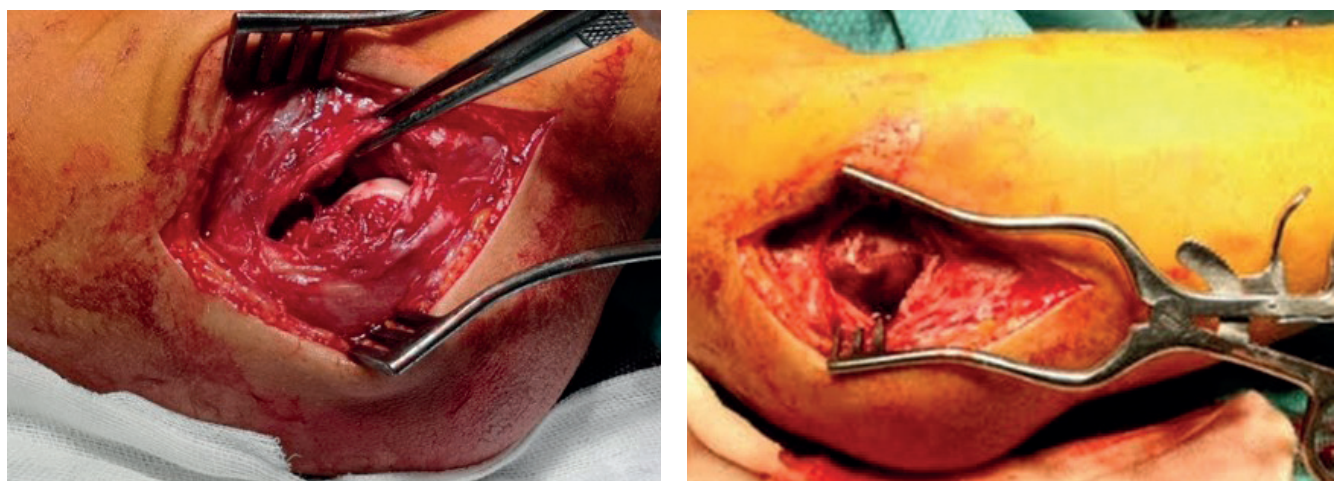

\section{5. ábra}

A lateralis condylusról leszakadt lateralis szalagrendszer 


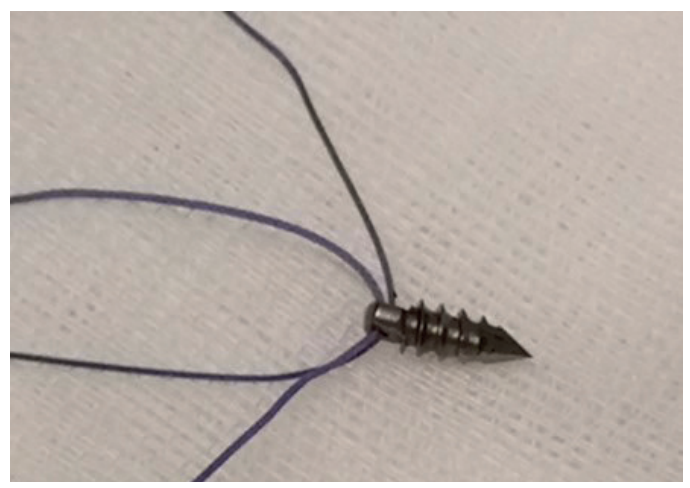

6. ábra

Két pár 0-ás Vicryllel töltött ORFI II-es horgony
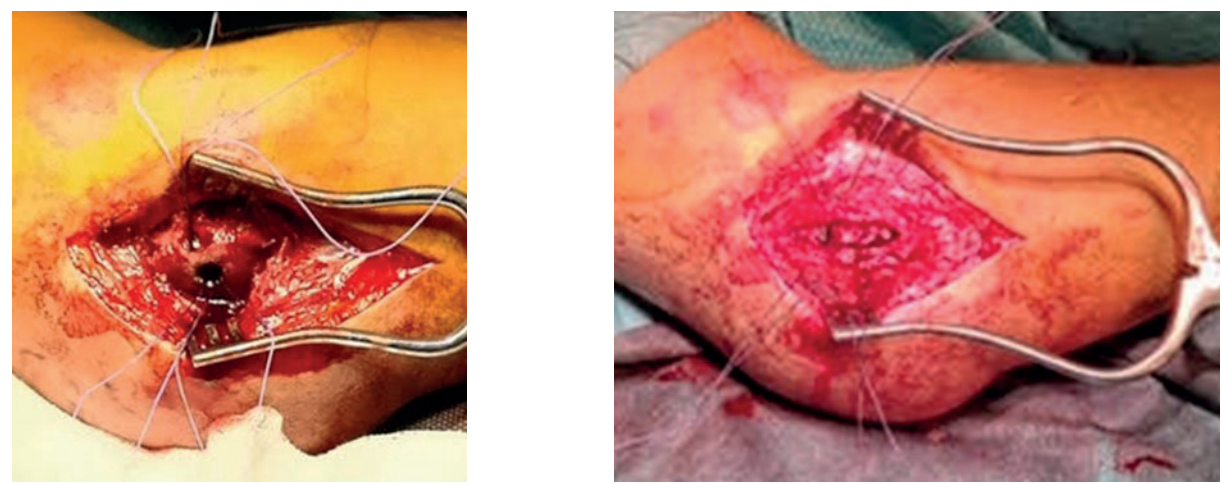

7. ábra

A horgonyok helyzete a lateralis epicondylus területén és a horizontális matrac öltések elhelyezése
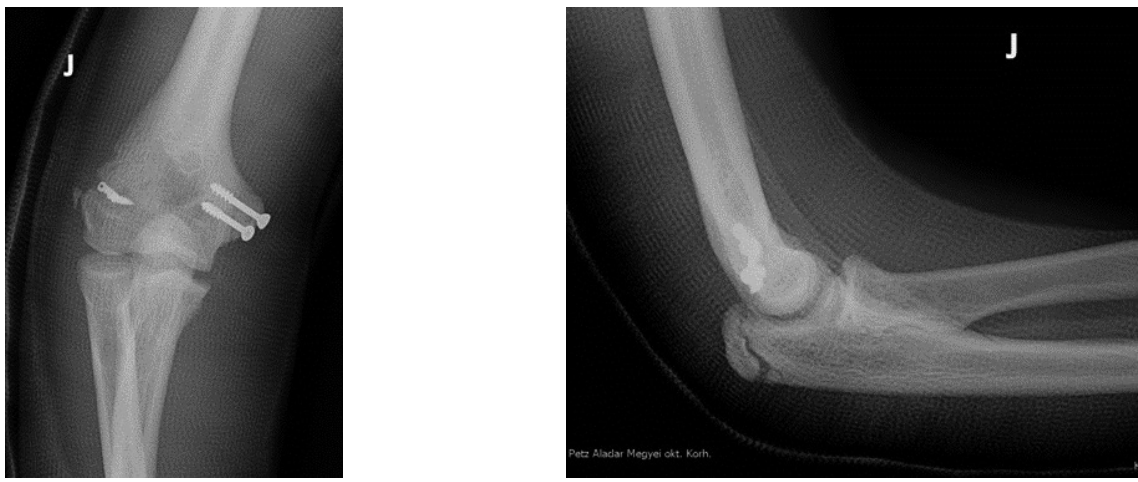

\section{8. ábra}

Posztoperativ állapot, magas dorsalis gipszsín rögzítésben 

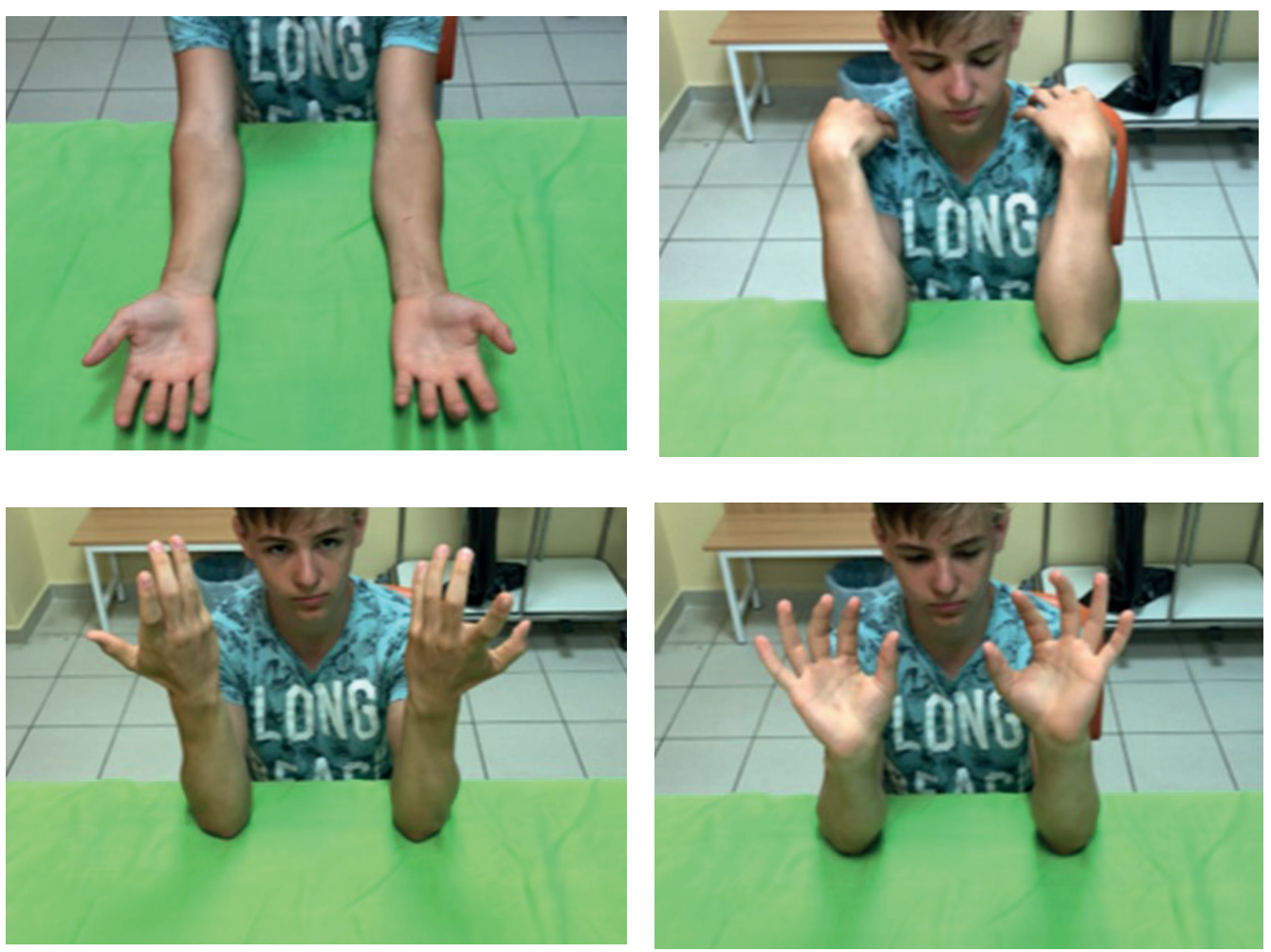

9. ábra

A 15 hetes kontrollvizsgálaton észlelt mozgástartomány

\section{MEGBESZÉLÉS}

A könyöktáji törések, ficamok esetében előforduló akut szövődmény lehet az ér- és idegsérülés (13), késői szövődményként pedig mozgáselmaradás (3) és korai arthrosis (2) jelentkezhet. Az így kialakult szövődmények jelentősen ronthatják a beteg munkaképességét és életminőségét.

Ficamok esetében, amennyiben fedett repozíció nem lehetséges és fennáll esetleges ér- és idegsérülés lehetősége, akut mútéti ellátás szükséges (5). Az interpositio sebészi megszűntetése után a repozíció már lehetségessé válik. Ezt követően fontos az intraoperatív pulzus ellenőrzése (pulzoxymeter használata) és a kérdéses idegek sebészi preparálása és folytonosságuk vizuális ellenőrzése a mútét során.

Jelen esetben egy teljes könyökízületi dezorganizációval álltunk szemben. Ilyen esetben mindenképpen kiemelten fontos a szalagrendszer - a medialis ulnaris collateralis szalag
(MUCL), a lateralis ulnaris collateralis szalag (LUCL) és a radialis collateralis szalag ( $R C L)$ minél stabilabb rekonstrukciója (4). Az MUCL bármelyik, elülső, vagy hátsó kötegének külön történő rekonstrukciója is nagymértékben növeli a könyök medialis oldali stabilitását (9). $\mathrm{Az}$ MUCL rekonstrukció esetében jelenleg a csavaros rögzítés megfelelő stabilitást biztosított, hiszen a letört medialis epicondylus elegendő nagyságú volt a csavarozáshoz. Ezáltal egyszerre, gyakorlatilag mindkét medialis köteg eredési területe rekonstruálásra került.

Ennél a sérülésnél a lateralis oldal is érintett volt. A lateralis szalagrendszer teljes szakadása - LUCL és RCL együtt - posterolateralis rotációs instabiltáshoz (PLRI) vezet. A lateralis szalagrendszer sérülésének leggyakoribb késői szövődménye a krónikus PLRI, amely gyakori lateralis könyöktáji fájdalmakban, néha pedig tényleges ízületi subluxatiókban, luxatiókban nyilvánul meg. Fizikális vizsgálata során végzett Pivot-Shift teszt sok esetben álnegativ 
eredményt mutat az izomzat stabilizálása miatt. A Pivot-Shift teszt igazán jól általános anesztézia bevezetése után vizsgálható (3). Ebből adódóan ilyen esetekben célszerű a lateralis collateralis szalagrendszer (LCL) egyidejú rekonstrukciója is (3). Az LUCL és $R C L$ esetében horgonyos rögzítést kellett alkalmazni az abruptiós csontdarabok kis mérete miatt. Fontos a horgonyok pontos elhelyezése a szalagrészek eredésének megfelelően, mert a fiziológiástól eltérő reinsertio befolyásolhatja az ízület mozgástartományát. A szalagrendszer akut sérülések során történt primer rekonstrukciója kitűnő és jó eredményeket biztosít (10).

A megfelelő ízületi stabilizáció legfontosabb előnye a gyógytorna korai megkezdésének lehetősége. Ennek révén a mozgástartomány mielőbbi visszatérése, ezáltal a külső rögzítés minél rövidebb ideig történő alkalmazása. Könyökízületi sérülések esetén rendkívül fontos, hogy az ízületet csak a lehető legrövidebb ideig rögzítsük $(7,8)$ és rögzítés mellett, annak naponta történő felfüggesztésével, minél előbb kezdje el a beteg a gyógytornát.

\section{ÖSSZEGZÉS}

Jelen esetben egy nagy dislocatióval járó komplex könyöksérüléssel álltunk szemben. Nem reponálható ficam esetén feltételezhető az interpositum jelenléte, mely csak mútéttel oldható meg. Repositiót követően alapvető fontosságú az instabilitás narkózisban történő vizsgálata, pontos felmérése. A szalagrendszer primer, anatómiai helyreállítása - sok esetben horgonyos refixatio segítségével - rendkívül fontos. A megfelelő izületi stabilitás mellett minél rövidebb ideig tartó rögzítés és minél előbb elkezdett, akár a külső rögzítés naponta történő többszöri felfüggesztése melletti gyógytorna és későbbi komplex rehabilitációs kezelés szükséges a megfelelő könyökfunkció visszanyeréséhez.

\section{IRODALOM}

1. Conti M. M., Caekebeke P., van Riet R.: Lateral collateral ligament injuries of the elbow - chronic posterolateral rotatory instability (PLRI). EFORT Open Rev. 2016. 1. (12): 461-468. https://doi.org/10.1302/2058-5241.160033

2. Debdut B., Wysocki R. W., Cohen M. S.: Primary and posttraumatic arthritis of the elbow. Arthritis. 2013; $2013: 473259$. https://doi.org/10.1155/2013/473259

3. Englert C., Zellner J., Koller M, Nerlich M., Lenich A.: Elbow dislocations: A review ranging from soft tissue injuries to complex elbow fracture dislocations. Adv. Orthop. 2013; 2013: 951397. https://doi.org/10.1155/2013/951397

4. Fekete K.: A könyökízület szalagsérülései. In: Renner A. (Szerk.) Szalagsérülések. Budapest, Kadixpress, 2010. pp. 175-189.

5. Fekete K.: Humerus distalis vég törése. Könyökficam. Myositis ossificans. In: Renner A. (szerk.) Traumatológia. 3. kiadás. Budapest, Medicina Könyvkiadó. 2011. 501-524. pp.

6. Kailash S., Shanmuganathan S.: Anterior dislocation of elbow with neurovascular injury: A rare case report. J. Orthop. Case Rep. 2017. 7. (1): 91-94.

7. Maripuri S. N., Debnath U. K., Rao P., Mohanty K.: Simple elbow dislocation among adults: a comparative study of two different methods of treatment. Injury. 2007. 38: 1254-1258. https://doi.org/10.1016/i.injury.2007.02.040

8. Mehlhoff T. L., Noble P. C., Bennett J. B., Tullos H. S.: Simple dislocation of the elbow in the adult. Results after closed treatment. J. Bone Joint Surg. Am 1988. 70: 244-249. https://doi.org/10.2106/00004623-198870020-00013

9. Rahman M., Cil A., Stylianou A. P.: Medial collateral ligament deficiency of the elbow joint: a computational approach. Bioengineering (Basel). 2018. 5. (4): 84. https://doi.org/10.3390/bioengineering5040084

10. Sanches S. J., Morrey B. F., O'Driscoll S. W.: Ligamentous repair and reconstruction for posterolateral rotatory instability of the elbow. J. Bone Joint Surg. Br. 2005. 87. (1): 54-61. https://doi.org/10.1302/0301-620X.87B1.15096

11. Lawrence S. H.: Anterior dislocation of the elbow with fracture of the olecranon. Am. J. Surg. 1948. 75. (5): 700-703. https://doi.org/10.1016/0002-9610(48)90394-8

12. Tees F. J.: Anterior dislocation at the elbow joint. Ann Surg. 1923. 77. (5): 612-614.

13. Wilkins K. E.: Fracture and dislocations of elbow region. In: Rockwood C. A., Wilkins K. E., King R. E. (Eds.): Fractures in chlidren. Vol. 3. 4. ed. Philadelphia etc. Lippincott. 1996. 653-887. pp.

14. Zhang D., Nazarian A., Rodriguez E. K.: Post-traumatic elbow stiffness: Pathogenesis and current treatments. Shoulder Elbow. 2020. 12. (1): 38-45. https://doi.org/10.1177/1758573218793903

\section{Dr. Nyőgér Zoltán}

Petz Aladár Megyei Oktató Kórház

Orthopaediai Osztály, Balesetsebészeti és Kézsebészeti Osztály

9023 Győr, Vasvári P. u. 2.-4.

E-mail: nyogerzoltan@gmail.com 